\title{
Cytomegalovirus co-infection with HIV in children and adolescents on antiretroviral therapy in Abuja, Nigeria
}

\author{
${ }^{1 *}$ Okechukwu, A. A., and ${ }^{2}$ Thairu, Y. \\ ${ }^{1}$ Deparment of Paediatrics, University of Abuja Teaching Hospital, Gwagwalada, Abuja, Nigeria \\ ${ }^{2}$ Department of Microbiology, University of Abuja Teaching Hospital, Gwagwalada, Abuja, Nigeria \\ Correspondence to: nebokest@yahoo.com; +2348036719906
}

\begin{abstract}
:
Background: Cytomegalovirus (CMV) co-infection with human immunodeficiency virus (HIV) is known to accelerate HIV disease progression. It has the potential of being a killer disease or a silent lifetime companion in HIV patients. There is dearth of information on CMV prevalence among HIV infected children and adolescents in our environment. We therefore conducted this study to determine its sero-prevalence, and risk factors for co-infection among HIV infected children and adolescents on highly active antiretroviral therapy (HAART) in our center.

Method: A descriptive cross sectional study of HIV-infected children and adolescents aged 2 months to 18 years on HAART was conducted over a 6 month period between October 2017 and March 2018 in our health facility. Blood samples of subjects were screened for CMV IgM using commercial test kits. Biodata of subjects, CD4 cell count, and viral load were collected into a designed proforma, and statistical analysis was done with SPSS version 22.0 .

Result: A total of $161 \mathrm{HIV}$-infected children and adolescents were recruited, $103(64.0 \%)$ were males, 83 (51.6\%) were between the ages of 5 and $<10$ years, $113(70.2 \%)$ were from lower socio-economic class, and 138 (85.7\%) were on $1^{\text {st }}$ line HAART. Of the $17(10.6 \%)$ subjects positive for CMV IgM, $3(17.6 \%)$ were less than 5 years old, $11(64.7 \%)$ were between the ages of 5-10 years, and none was older than 15 years. Univariate analysis showed significant differences in the mean age, weight, length/height, and systolic blood pressure between CMV IgM positive and negative patients $(p<0.05)$, but no significant difference in gender, socioeconomic class, types of antiretroviral drugs, CD4 cell count, and viral load $(p>0.05)$. Multivariate analysis however did not show any significant difference in age, weight, length/height, and systolic blood pressure.

Conclusion: The prevalence of active CMV infections among HIV infected children and adolescents on HAART in our centre is high. Low CD4 cell count and high viral load were not associated with active CMV disease, and no risk factor for co-infection was also identified. Identifying those with primary/active infection will be necessary for possible treatment with anti-herpes drugs before development of reactivated CMV disease.
\end{abstract}

Keywords: CMV; HIV; co-infection; anti-retroviral; children; adolescents

Received June 27, 2019; Revised October 10, 2019; Accepted October 12, 2019

Copyright 2020 AJCEM Open Access. This article is licensed and distributed under the terms of the Creative Commons Attrition 4.0 International License (http://creativecommmons.org/licenses/by/4.0), which permits unrestricted use, distribution and reproduction in any medium, provided credit is given to the original author(s) and the source.

\section{Co-infection par le cytomégalovirus et le VIH chez des enfants et des adolescents sous traitement antirétroviral à Abuja, au Nigéria}

\author{
${ }^{1 *}$ Okechukwu, A. A., et ${ }^{2}$ Thairu, Y.
}

${ }^{1}$ Département de pédiatrie, Hôpital universitaire de Abuja, Gwagwalada, Abuja, Nigéria

${ }^{2}$ Département de microbiologie, hôpital universitaire de Abuja, Gwagwalada, Abuja, Nigéria Correspondance à: nebokest@yahoo.com; +2348036719906

\section{Abstrait:}

Contexte: On sait que la co-infection par le cytomégalovirus (CMV) et le virus de l'immunodéficience humaine (VIH) accélère la progression de la maladie. Il a le potentiel d'être une maladie mortelle ou un compagnon 
silencieux à vie chez les patients VIH. Il existe peu d'informations sur la prévalence du CMV chez les enfants et les adolescents infectés par le VIH dans notre environnement. Nous avons donc mené cette étude pour déterminer sa séroprévalence et les facteurs de risque de co-infection chez les enfants et les adolescents infectés par le VIH sous traitement antirétroviral hautement actif (HAART) dans notre centre.

Méthode: Une étude transversale descriptive des enfants et adolescents infectés par le VIH et âgés de 2 mois à 18 ans sous multithérapie a été menée sur une période de 6 mois entre octobre 2017 et mars 2018 dans notre établissement de santé. Des échantillons de sang de sujets ont été testés pour l'IgM de CMV en utilisant des kits de test commerciaux. Les données biologiques des sujets, le nombre de cellules CD4 et la charge virale ont été recueillis dans un formulaire conçu à cet effet et une analyse statistique a été réalisée avec SPSS version 22.0 . Résultat: 161 enfants et adolescents infectés par le VIH ont été recrutés, dont $103(64,0 \%)$ étaient des hommes, $83(51,6 \%)$ étaient âgés de 5 à moins de 10 ans, $113(70,2 \%)$ étaient issus de milieux socio-économiques inférieurs. et $138(85,7 \%)$ suivaient la multithérapie de première ligne. Sur les $17(10,6 \%)$ sujets positifs pour l'IgM du CMV, $3(17,6 \%)$ avaient moins de 5 ans, $11(64,7 \%)$ étaient âgés de 5 à 10 ans et aucun n'avait plus de 15 ans. Une analyse univariée a montré des différences significatives dans l'âge moyen, le poids, la taille / taille et la pression artérielle systolique entre les patients positifs et négatifs pour IgM anti-CMV $(p<0,05)$, mais aucune différence significative entre le sexe, la classe socio-économique, les types de médicaments antirétroviraux et les cellules CD4 nombre et charge virale $(p>0,05)$. L'analyse multivariée n'a cependant montré aucune différence significative d'âge, de poids, de taille / taille et de pression artérielle systolique.

Conclusion: La prévalence des infections à CMV actives chez les enfants et les adolescents infectés par le VIH sous HAART dans notre centre est élevée. Un faible nombre de cellules CD4 et une charge virale élevée n'étaient pas associés à la maladie à CMV active et aucun facteur de risque de co-infection n'a également été identifié. Identifier les personnes présentant une infection primaire / active sera nécessaire pour un traitement éventuel avec des médicaments anti-herpès avant le développement d'une maladie à CMV réactivée.

Mots-clés: CMV; HIV; co-infection; anti-rétroviral; Enfants; les adolescents

\section{Introduction:}

Cytomegalovirus also known as human herpes virus (HHV) 5 is one of the eight HHVs, belonging to beta herpesvirus subfamily. Infection is ubiquitous, and generally asymptomatic in healthy children and adults. Infants usually acquire the infection while in the uterus, during passage through the birth canal, or through breast milk. Young children are frequently infected by contaminated saliva when sucking and sharing toys. The virus can also be contacted through respiratory routes, pharyngeal secretions, tears, urine, faeces, seminal and vaginal fluids, during blood transfusion, organ transplant, or through sexual contact (1). Infection is largely contacted during childhood or during sexual activities in human population worldwide with some regional variations (1). Following primary infection, the virus becomes latent in a few cells in its episomal form (2). Reactivation with viral shedding occurs when immunity is compromised as seen in HIV co infection (2).

CMV is widely recognized as an opportunistic pathogen causing severe opportunistic infections in immuno-compromised individuals which generally manifests as retinitis with high tendency to cause rapid loss of vision, chronic crippling diarrhea, central nervous system diseases and sudden loss of neurologic function, and pneumonia $(3,4)$. CMV active infection might be a marker of extremely severe immunosuppression that can ultimately lead to a fatal outcome in immuno- compromised individual. Primary CMV infection occurs in a previously sero-negative individual and can be a potential killer in such individual, whereas secondary infection which is intermittent excretion of the virus in the presence of host immunity may be due to either reactivation of an endogenous virus or exposure to a new virus strain from an exogenous source. (5). Hence the presence of the IgM antibodies may be due to primary/active infection or re-infection (6).

Persistent immune activation is hallmark of human immunodeficiency virus infection, and in co-infected individual, CMVinduced $T$ cell activation potentially contributes to increased HIV disease progression (7). The two viruses while infecting a number of similar cell types such as the endothelium of blood vessels, mononuclear cells, white blood cells, and epithelial cells, also interact through transactivation, secretion of cytokines that reactivate provirus, or increase in HIV tropism through CMV expression of receptor analogues or by formation of pseudoviruses (8). HIV infection induces immunosuppression through depletion of CD4 cell count with increasing CMV reactivation, the reactivation promote HIV replication through a complex interaction with the long terminal repeat region, transactivation of proviral HIV, release of inflammatory cytokines and chemokines, and up-regulation of CCR5 expression in central memory T cells (9-11). During the era of antiretroviral therapy (ART), accumulated data in adults suggests that CMV co-infection with HIV contributes 
significantly to the accelerated HIV disease progression and development of non AIDSdefining comorb- idities (12-17). The complex interplay of these two chronic viral infections continues to be potentially significant especially in highly endemic area of subSaharan Africa, where both viruses are endemic (18).

In industrialized countries such as USA, Australia and Europe, CMV sero-prevalence among adult population is between 36 and $77 \%$, in contrast to highly endemic areas of sub-Saharan Africa, where sero-prevalence approaches $100 \%$ (19). There is serological evidence of CMV infection in almost two thirds of infants from African origin by 3 months of age, and $85 \%$ are infected by a year (20). Among HIV-infected children in Africa, the majority are co-infected with CMV by their first birthday (20) and almost all by the time they reach their teens, in contrast to what is seen in industrialized nations $(7,21)$.

Antibody testing can be used to determine recent or past exposure to CMV infection. The first antibody to develop in response to CMV infection is IgM. This develops within a few days following primary infection. While CMV IgM remains detectable for six to nine months in the blood, medium to high levels of CMV IgM can be detected during the first three months of a primary infection. IgM is also detected during secondary infections either as re-activation or reinfection. By assessing the presence of IgM in a sample, active CMV infection can be ascertained. This study was therefore conducted to determine the prevalence of active CMV infection in HIV infected children and adolescents on ART in our health facility. The study also aimed to determine the risk factors for acquisition of the CMV, and the effects of co-infection on CD4 cell count and viral load of HIV patients.

\section{Materials and method:}

\section{Study setting and design}

A cross sectional hospital based study was conducted at the Paediatric Out-patient Special Treatment Clinic (POSTC) of the University of Abuja Teaching Hospital (UATH) over a 6 months period from October 2017 to March 2018. POSTC is an arm of out-patient service area of department of paediatrics where HIV infected children/adolescents and exposed babies are seen and followed up for treatment/monitoring. The clinic is opened for services from Monday-Friday, and from 7.30 am to $4 \mathrm{pm}$. UATH is a 350 bed capacity referral hospital, sub-serving the people of Federal Capital Territory (FCT) Abuja and neighbouring states of Nassarawa, Kogi, Kaduna, and Niger States. It is one of the first centers since 2005 to start offering free HIV/AIDS services in the country through the President Emergency Plan for AIDS Relief (PEPFAR) and the Federal Government of Nigeria (FGN).

\section{Subjects}

The subjects were paediatric patients' 2 months to 18 years old tested positive for HIV by either serological method or by polymerase chain reaction (PCR) test and started on anti retroviral therapy (ARV) therapy. Consecutive eligible children and adolescents attending the POSTC were recruited and subsequently enrolled into the study after parents/caregivers provided written informed consent and children 7 years and above provided assent for the study. Inclusion criteria for the study were; HIV infected children and adolescents aged 2 months to 18 years on ARV therapy, parents/caregivers and older children accepting to be part of the study. Exclusion criteria included those unwilling to participate in the study, and exposed uninfected infants. Ethics clearance was obtained from the ethics committee of the hospital before the commencement of the study.

\section{Clinical data and sample collection}

Clinical and physical examination were carried out after enrollment by the attending physician. The demographic characteristics of the subjects were collected which included age, gender, religion, and socio economic statue (SES) of the parents. Using a vaccutainer needle, three milliliters ( $3 \mathrm{mls}$ ) of venous blood was collected from each subject and transported to the laboratory for analysis. In addition, the weight, blood pressure, CD4 cell count, and viral loads (VL) were retrieved from the patient's information record if done within 1 month of the study or if not, they were freshly performed.

\section{Laboratory analysis}

The serum was separated by centrifugation at $3500 \mathrm{rpm}$ for 5 minutes and refrigerated $\left(2-8^{\circ} \mathrm{C}\right)$ until analysis was done. At the time of analysis, the serum was carefully removed using a fine bore pipette to avoid extracting red cells and the test device removed from the sealed pouch. Screening for CMV IgM was done using commercial fortress diagnostics $^{\mathrm{R}}$ (CMV IgM) ELISA immunoassays 
kits. The clinical sensitivity and specificity of the Cyto IgM ELISA kits was $99.6 \%$ on plasma and sera. The cut-off optical density (O.D) was obtained in accordance with the manufacturer's instructions; the CMV index of the samples was calculated by dividing the O.D value of each of the samples with the obtained Cut-off O.D values. OD interpretation was $\mathrm{CMV}$ index of $<0.90$ as negative and CMV index of 1.0 and above as positive.

CD4 cell count was measured using automated Partec Cyflow easy count kit (Partec code no. 05-8401 Western Germany), Viral load (VL) measurement was performed with Roche Smp/prep/cobs Taqman 96, USA, and Seca beam weighing scale was used to accurately measure weight to the nearest $0.01 \mathrm{~kg}$.

\section{Data analysis}

Data analysis was done using SPSS version 22.0, and percentage, means and standard deviations were calculated for the variables. The test for association was done using student t-test for continuous variables and Chi-square or Fisher's exact test for categorical variables where applicable. Multivariate logistic model was used to determine associated risk factors of CMV coinfection with HIV, unadjusted and adjusted odds ratio (OR) were reported, and $p$ value of $<0.05$ was considered significant.

\section{Results:}

Table 1 shows the demographic and clinical characteristics of the study population. Of a total of $161 \mathrm{HIV}$ infected children and adolescents screened for CMV IgM antibody, $103(64.0 \%)$ were males, $83(51.6 \%)$ were between the ages of $5-10$ years, 110 (68.3\%) were Christians, 113 (70.2\%) were from low socio-economic class and $138(85.7 \%)$ were on $1^{\text {st }}$ line HAART. The mean body weight, CD4 cell count and VL were $30.0 \pm 12.4 \mathrm{~kg}$, $979.5 \pm 457.7$ cells $/ \mu \mathrm{l}$, and $9,136.1 \pm 306.0$ copies/ml. There was no significant difference in the demographic characteristics between the male and female populations ( $p>0.05$ for all the variables).

Table 2 shows the association of CMV IgM antibody and the co-variables. Seventeen $(10.6 \%)$ of the 161 patients screened tested positive for the IgM antibody, while 144 $(89.4 \%)$ were negative. Three $(17.6 \%)$ of those tested positive were less than 5 years, $11(64.7 \%)$ were between the ages of 5 and $<10$ years, and none was older than 15 years. On univariate analysis, significant difference was observed in mean age $(p=0.025)$, body weight $(p=0.004)$, length/height $(p=0.039)$, and systolic blood pressure $(p=0.001)$ between those who tested positive and negative for the CMV IgM. On multivariate logistic regression, none of the associated factors (age, body weight, length/height, and systolic blood pressure) showed significant association with CMV infection ( $p>0.05)$ (Table 3).

Although there were more male subjects $(10,58.8 \%)$, subjects in the age range of $5-<10$ years $(11,64.7 \%)$, Christians $(9,52.9 \%)$, subjects from low socio-economic class $(16,94.1 \%)$, and subjects on 1st line ART $(15,88.2 \%)$ who tested positive for CMV IgM, the difference was not significantly different from CMV IgM negative subjects ( $p>0.05$ for all the variables). Similarly, there were no statistically significant differences for other parameters; CD4 cell count, VL, BMI, ART duration, and diastolic blood pressure between those positive and negative for CMV IgM ( $p>0.05$ for all variables).

Table 4 depicts the different values of CD4 cell count and VL in relation to CMV IgM positivity and negativity. Only 1 (5.9\%) patient with CD4 cell count of $<200$ cells/ $\mu$ l and 2 $(11.8 \%)$ with VL of $>1000$ copies $/ \mathrm{ml}$ tested positive for CMV IgM. There was no significant difference in the values of CD4 cells and VL between CMV IgM positive and negative patients $(p>0.05)$.

\section{Discussion:}

The prevalence of active or primary CMV infection in HIV infected children and adolescents on highly active anti-retroviral therapy (HAART) in this study, was $10.6 \%$. This was comparable to $13 \%$ among HIV infected adolescents and adults from Kano by Musa et al., (22), 9.5\% among AIDS patients from India by Basawaraju et al., (23) and $11.4 \%$ among infected prison inmates by Neusa et al., (24) in Brazil. The rate in our study is however much lower than $58.3 \%$ reported among HIV-infected infants initiated on ART in Cameroun by Kfutwah et al.,(26), $28 \%$ by Oladipo et al., (27) among blood donors in Nigeria, and $14 \%$ among HIV patients by Tsertsvadze et al., (28). The prevalence rates of $3.5 \%(29), 4.5 \%(30)$, $6.6 \%(31), 7.0 \%(32), 8.1 \%(33)$, and $8.4 \%$ (25) from various studies in Nigeria, Qatar, and Kenya were lower than the $10.6 \%$ recorded in this study. Although most of these referenced studies were from adult population, pregnant women and blood donors, with only two from HIV children and adolescents, the 
Table 1: Demographic and clinical characteristics of HIV-infected children and adolescents in University of Abuja Teaching Hospital, Gwagwalada, Abuja, Nigeria

\begin{tabular}{|c|c|c|c|c|}
\hline Characteristics of subjects & Male $(\%)$ & Female (\%) & Total (\%) & $p$ value \\
\hline No of subjects & $103(64.0)$ & $58(36.0)$ & $161(100)$ & 0.64 \\
\hline \multicolumn{5}{|l|}{ Age group (years) } \\
\hline$<5$ & $11(10.7)$ & $2(3.4)$ & $13(8.1)$ & \\
\hline $5-<10$ & $52(50.4)$ & $31(53.4)$ & $83(51.6)$ & \\
\hline $10-15$ & $32(31.1)$ & $21(36.2)$ & $53(32.9)$ & \\
\hline$>15$ & $8(7.8)$ & $4(6.9)$ & $12(7.4)$ & 0.423 \\
\hline \multicolumn{5}{|l|}{ Religion } \\
\hline Christianity & $74(71.8)$ & $36(62.1)$ & $110(68.3)$ & \\
\hline Islam & $29(28.2)$ & $22(37.9)$ & $51(31.7)$ & 0.201 \\
\hline \multicolumn{5}{|l|}{ Socio-economic class } \\
\hline High & $11(10.7)$ & $5(8.6)$ & $16(9.9)$ & \\
\hline Middle & $22(21.4)$ & $10(17.2)$ & $32(19.9)$ & \\
\hline Low & $70(67.9)$ & $43(74.1)$ & $113(70.2)$ & 0.764 \\
\hline \multicolumn{5}{|l|}{$1^{\text {st }}$ or $2^{\text {nd }}$ line ARVT } \\
\hline $\begin{array}{l}1^{\text {st }} \text { Line } \\
2^{\text {nd }} \text { Line }\end{array}$ & $\begin{array}{l}89(86.4) \\
14(13.6)\end{array}$ & $\begin{array}{l}49(84.5) \\
9(15.5)\end{array}$ & $\begin{array}{l}138(85.7) \\
23(14.3)\end{array}$ & 0738 \\
\hline ARVT duration (years)* & $6.7 \pm 3.3$ & $7.0 \pm 3.5$ & $6.9 \pm 3.4$ & 0.695 \\
\hline \multicolumn{5}{|l|}{ Wt, CD4 and Viral Load* } \\
\hline Weight (kg) & $29.9 \pm 12.2$ & $30.1 \pm 12.5$ & $30.0 \pm 12.4$ & 0.962 \\
\hline CD4 (cells/ul) & $904.8 \pm 139.5$ & $1054.1 \pm 75.9$ & $958.6 \pm 37.8$ & 0.058 \\
\hline Viral Load (copies/ml) & $18507.9 \pm 440.6$ & $6206.6 \pm 343.4$ & $9136.1 \pm 306.0$ & 0.314 \\
\hline
\end{tabular}

Table 2: Clinical variables in HIV-infected children and adolescents with CMV co-infections in University of Abuja Teaching Hospital, Gwagwalada, Abuja, Nigeria

\begin{tabular}{|c|c|c|c|c|c|}
\hline $\begin{array}{l}\text { Clinical and associated } \\
\text { risk factors/variables }\end{array}$ & $\begin{array}{c}\text { CMV positive } \\
(\%)\end{array}$ & $\begin{array}{c}\text { CMV negative } \\
(\%)\end{array}$ & Total (\%) & $\mathbf{X}^{2}$ & p value \\
\hline Subjects & $17(10.6)$ & $144(89.4)$ & $161(100)$ & & \\
\hline \multicolumn{6}{|l|}{ Age Group (years) } \\
\hline$<5$ & $3(17.6)$ & $10(6.9)$ & $13(8.1)$ & 5.558 & 0.135 \\
\hline $5-<10$ & $11(64.7)$ & $72(50.0)$ & $83(51.6)$ & & \\
\hline $10-15$ & $3(17.6)$ & $50(34.7)$ & $55(34.2)$ & & \\
\hline$>15$ & 0 & $12(8.3)$ & $16(9.9)$ & & \\
\hline \multicolumn{6}{|l|}{ Gender } \\
\hline $\begin{array}{l}\text { Male } \\
\text { Female }\end{array}$ & $\begin{array}{c}10(58.8) \\
7(41.2)\end{array}$ & $\begin{array}{l}93(64.6) \\
51(35.4)\end{array}$ & $\begin{array}{c}103(63.9) \\
58(36.0)\end{array}$ & 0.98 & 0.647 \\
\hline \multicolumn{6}{|l|}{ Religion } \\
\hline Christianity & $9(52.9)$ & $101(70.1)$ & $110(68.3)$ & 2.078 & 0.149 \\
\hline Islam & $8(47.1)$ & $43(29.9)$ & $51(31.7)$ & & \\
\hline \multicolumn{6}{|l|}{ Socio-economic class } \\
\hline High & 0 & $16(11.1)$ & $16(9.9)$ & 0.912 & 0.634 \\
\hline Middle & $1(5.9)$ & $31(21.5)$ & $32(19.9)$ & & \\
\hline $\begin{array}{l}\text { Low } \\
\text { Tynes of ARY Druas }\end{array}$ & $16(94.1)$ & $97(67.4)$ & $113(70.2)$ & & \\
\hline $\begin{array}{c}\text { Types of ARV Drugs } \\
1^{\text {st }} \text { line } \\
2^{\text {nd }} \text { line }\end{array}$ & $\begin{array}{l}15(88.2) \\
2(11.7)\end{array}$ & $\begin{array}{l}123(85.4) \\
21(14.5)\end{array}$ & $\begin{array}{c}138(85.7) \\
23(14.3)\end{array}$ & 0.099 & 0.753 \\
\hline Co-variables* & CMV positive (\%) & CMV negative (\%) & Mean value & T- test & p value \\
\hline ARV duration (years) & $5.41 \pm 3.1$ & $6.97 \pm 3.4$ & $6.2 \pm 3.3$ & 1.81 & 0.074 \\
\hline Weight (kg) & $22.0 \pm 5.5$ & $31.0 \pm 12.5$ & $26.5 \pm 9.0$ & 5.14 & $0.004 * *$ \\
\hline Length/height $(\mathrm{cm})$ & $125.3 \pm 12.3$ & $135.7 \pm 20.0$ & $130.5 \pm 16.2$ & 3.28 & $0.039 * *$ \\
\hline BMI $\left(\mathrm{kg} / \mathrm{m}^{2}\right)$ & $13.9 \pm 1.9$ & $16.9 \pm 7.9$ & $15.4 \pm 4.9$ & 0.711 & 0.164 \\
\hline Systolic BP (mmHg) & $86.2 \pm 9.7$ & $94.1 \pm 9.4$ & $90.2 \pm 9.6$ & 6.39 & $0.001 * *$ \\
\hline Diastolic BP $(\mathrm{mmHg})$ & $53.5 \pm 7.8$ & $57.2 \pm 9.4$ & $55.4 \pm 8.6$ & 0.64 & 0.119 \\
\hline CD4 $($ cells $/ \mu l))$ & $919.6 \pm 34.1$ & $1009.9 \pm 23.7$ & $958.6 \pm 37.8$ & 0.69 & 0.144 \\
\hline Viral Load (copies/ml) & $10562.8 \pm 357$ & $14491 . \pm 774.1$ & $9136.1 \pm 306.0$ & 0.87 & 0.837 \\
\hline
\end{tabular}

$\mathrm{ARV}=$ antiretroviral therapy, $*=$ mean values; $* *=$ significant difference; $\mathrm{X}^{2}=$ Chi square value 
Table 3: Multivariate logistic regression of associated risk factors for CMV infection in HIV-infected children and adolescents in University of Abuja Teaching Hospital, Gwagwalada, Abuja, Nigeria

\begin{tabular}{ccccc}
\hline Variables & $\begin{array}{c}\text { Unadjusted OR } \\
(95 \% \mathrm{CI})\end{array}$ & $p$ value & $\begin{array}{c}\text { Adjusted OR } \\
(95 \% \mathrm{CI})\end{array}$ & $p$ value \\
\hline Age & $0.7-0.975$ & 0.017 & $0.85-1.17$ & 0.954 \\
Constant & & 0.545 & 0.924 & 0.055 \\
Weight & $0.85-0.974$ & 0.007 & 0.99 & 0.924 \\
Constant & & 0.685 & $0.98-1.146$ & 0.094 \\
Length/Height & $0.95-0.99$ & 0.049 & $0.88-1.015$ & 0.118 \\
Constant & & 0.501 & 0.002 & 0.924 \\
Systolic Blood Pressure & $0.86-0.968$ & 0.020 & & \\
$\quad$ Constant & & & & \\
\hline
\end{tabular}

$\mathrm{OR}=$ odd ratio; $\mathrm{CI}=$ confidence interval

Table 4: CD4 cell count and Viral Load of HIV infected children and adolescents with CMV IgM in University of Abuja Teaching Hospital, Gwagwalada, Abuja, Nigeria

\begin{tabular}{|c|c|c|c|c|c|}
\hline Variables & $\begin{array}{l}\text { CMV IgM positive } \\
(\%)\end{array}$ & $\begin{array}{c}\text { CMV IgM negative } \\
(\%)\end{array}$ & Total (\%) & $\mathrm{X}^{2}$ & $p$ value \\
\hline \multicolumn{6}{|c|}{ CD4 cell count (cells/ $\mu \mathrm{l})$} \\
\hline$<200$ & $1(5.9)$ & $2(1.4)$ & $3(1.9)$ & 2.631 & 0.268 \\
\hline $200-500$ & $1(5.9)$ & $22(15.3)$ & $23(14.3)$ & & \\
\hline$>500$ & $15(88.2)$ & $120(83.3)$ & $135(83.8)$ & & \\
\hline \multicolumn{6}{|l|}{ Viral Load (copies/ml) } \\
\hline$<20$ & $10(58.8)$ & $65(45.1)$ & $75(46.6)$ & 1.389 & 0.499 \\
\hline $20-1000$ & $5(29.4)$ & $48(33.3)$ & $53(32.9)$ & & \\
\hline$>1000$ & $2(11.8)$ & $31(21.5)$ & $33(20.5)$ & & \\
\hline
\end{tabular}

$\mathrm{CD}=$ clusters of differentiation $; \mathrm{CMV}=$ cytomegalovirus; IgM = immunoglobulin $\mathrm{M} ; \mathrm{X}^{2}=$ Chi square

differences however might not be unrelated to geographical locations of the studies, study populations, ethnic, social, cultural, and economic differences, and different sensitivity of the IgM screening tests used (34).

The high prevalence of active CMV infection in HIV children and adolescents in our study could signify either high level of primary infection or new strain of reactivated infections. This should be worrisome in this highly endemic area where vaccines for CMV have not yet been developed. However, the fact that all the patients in this study were on HAART with no clinical evidences of severe immune suppression such as retinitis, chronic crippling diarrhea, or other features of AIDS from CMV co-infection may suggest other associated factor(s) in the etiology of coinfection. Akinbami et al., (29) and Klatt and Shibata (36), however attributed such clinical manifestations of co-infection to reactivation of previous CMV infection rather than primary infection.

Our study showed non-statistically significant higher prevalence rate of CMV IgM in the male than female subjects, which is similar to the observations of Ojide et al., (31) and Fowotade et al., (35) among their HIVinfected adults cohort. Musa et al., (22) however had a contrary observation in Kano where they reported more female patients living with HIV having significantly higher CMV IgM than their male counterparts $(8.7 \%$ vs $4.3 \%, p<0.01$ ) although no reason for such finding was proffered. Udeze et al., (37) equally found significantly higher primary/ active CMV IgM among males than females HIV-infected children and adults on ART in their study cohort in Ilorin, and attributed such findings to more exposure of males to factors that lead to re-activation or re-infection of CMV in their locality.

There was also non-statistically significant highest prevalence of CMV IgM among subjects in $5-<10$ year age group $(64.7 \%)$ when compared to other paediatric age groups in this study $(p=0.135)$. This is the period when parents usually send their children to day care services, nursery or primary schools. CMV transmission among children in 
day care centers may be enhanced as a result of poor hand hygiene practices and overcrowding usually seen in such care centres (38). Exposure of children to such centers therefore increase the risk of CMV cross infection from school mates. Other studies however have shown significant association between prevalence of active CMV infection and other age groups $(35,37)$. In the study by Udeze et al., (37), higher IgM was significantly observed among children in age group $\leq 20$ years $(p=0.047)$ among their HIV cohorts aged 1 to 70 years on ART studied at Ilorin. The authors attributed such significant positive findings to the lower level of education and engagement in risky sexual behaviours in the age group but because the study did not separate the children into different paediatric age groups, it was difficult to appreciate which particular age group among the children had the highest prevalence of CMV IgM. CMV infection is ubiquitous with primary/active infection occurring commonly during childhood or adulthood in 4 out of every 5 person above 35 years old, but the infection is usually very mild and generally unrecognized (39).

Many previous studies identified low socio-economic class (SEC) as a risk factor for CMV infection $(6,15,17)$. Our study however showed no significant association between low SEC and CMV IgM in the children and adolescents $(p=0.634)$. Basha et al., (40) equally observed no significant association between CMV sero-prevalence and SEC $(p=0.58)$ in their prospective cohort of non HIV Australian children aged 0-15 years. They however reported more congenital CMV in individuals with high SEC (55\%) than the low SEC $(9 \%) \quad(p<0.001)$. Our study shows significant association between CMV IgM with respect to mean age, mean body weight, length/height and mean systolic blood pressure in the univariate analysis. These significant findings were not surprising considering that IgM were seen in younger age groups (none seen in >15years), and these variables were all age dependent. However on multivariate logistic analysis, all these variables were not statistically significant.

Low CD4 cell count in HIV infected person and high VL are indications of poor immunity and inadequate viral suppression. Although the prevalence of CMV IgM was higher among patients with high CD4+ cell counts and low VL in our study, this surprisingly, was not statistically significant. Similar studies in Benin (31) and Ilorin (37) in Nigeria, and in Iran (41) also found no statistically significant association between
CD4+ cell count values and prevalence of CMV IgM in their study populations, and adduced such findings to the effects of ART and duration of treatment. Patients in the present study had mean CD4 cell count and ART treatment duration of $958.6 \pm 37.8$ cells $/ \mu$ l and $6.9 \pm 3.4$ years respectively, indicating adequate immune response and long duration on ART. Going by the suggestion of Ojide et al., (31) and Udeze et al., (37), the good immunological response of patients in our study and their long duration on ART could possibly explain the non-significant association between prevalence of CMV IgM and CD4 cell count and VL. However, many other studies have shown prevalence of CMV IgM to be significantly associated with CD4 cell count $(22,40,41)$. Although significant association was observed between CD4 cell count and prevalence of CMV IgM among HIV infected patients in the study by Musa et al., (22), the authors noted that there was no positive correlation between CD4 cell count and the prevalence of CMV IgM.

\section{Conclusion:}

Our study reports high prevalence of CMV IgM, indicating active/primary CMV infection among HIV infected children and adolescents on HAART. This prevalence was not significantly associated with low CD4 cell count, high VL or any risk factor. Identifying those with primary/active infection is necessary for possible treatment with anti-herpes drugs before development of reactivated CMV disease.

\section{References:}

1. McGeoch, D. J., Cook, S., Dolan, A., Jamieson, F. E., and Telford, E. A. Molecular phylogeny and evolutionary timescale for the family of mammalian herpesviruses. J Mol Biol. 1995; 247: 443-458

2. Fishman, J. A. Overview: cytomegalovirus and the herpesviruses in transplantation. Am J Transplant. 2013; 13: 1-8

3. Drew, W. L. Cytomegalovirus infection in patients with AIDS. Clin Infect Dis. 1992; 14: 608- 615.

4. Gona, P., Van Dyke, R. B., Williams, P. L., et al. Incidence of opportunistic and other infections in HIV-infected children in the HAART era. JAMA. 2006; 296: 292- 300.

5. Vauloup-Fellous, C. M., Berth, M., Heskia, F., Dugua, J. M., and Grangeot-Keros, L. Reevaluation of the VIDAS Cytomegalovirus (CMV) IgG avidity assay: Determination of new cut-off values based on the study of kinetics of CMV-IgG maturation. J Clin Virol. 2013; 56: 118-123

6. Chakravarti, A, Kashyap, B, and Metlani, M. Cytomegalovirus Infections: An Indian Perspective. Indian J Med Microbiol. 2009; 27: 3 11. 
7. Kovacs, A., Schluchter, M., Easley, K., Demmler. G., et al. Cytomegalovirus infection and HIV-1 disease progression in infants born to HIV-1infected women. Pediatric pulmonary and cardiovascular complications of vertically transmitted HIV infection study group. N Engl ] Med. 1999; 341: 77-84.

10.1056/NEJM199907083410203

8. Griffiths, P. D. CMV as a cofactor enhancing progression of AIDS. J Clin Virol. 2006; 35: 489492

9. Crough, T., and Khanna, R. Immunobiology of human cytomegalovirus: from bench to bedside. Clin Microbiol Rev. 2009; 22: 76-98. 10.1128/CMR.00034-08

10. Lichtner, M., Cicconi, P., Vita, S., et al. Cytomegalovirus co-infection is associated with an increased risk of severe non-AIDS-defining events in a large cohort of HIV-infected patients. J Infect Dis. 2015 ; 211: 178-186. 10.1093/infdis/jiu417.

11. Iwamoto, G. K., and Konicek, S. A Cytomegalovirus immediate early genes upregulate interleukin-6 gene expression. J Investig Med. 1997; 45: 175- 182

12. Brunt, S. J., Cysique, L. A., Lee, S., Burrows, S., Brew, B. J., and Price, P. Short Communication: Do cytomegalovirus antibody levels associate with age-related syndromes in HIV patients stable on antiretroviral therapy? AIDS Res Hum Retroviruses. 2016; 32 (6): 567-572.

13. Gianella, S., Massanella, M., Wertheim, J. O, and Smith, D. M. The Sordid Affair between Human Herpesvirus and Human Immunodeficiency Virus. J Infect Dis. 2015: jiv148.

14. Freeman, M. L., Lederman, M. M., and Gianella, S Partners in Crime: The Role of CMV in Immune Dysregulation and Clinical Outcome During HIV Infection. Curr HIV/AIDS Rep. 2016; 13 (1): 1019.

15. Seale, H., MacIntyre, C. R., Gidding, H. F., Backhouse, J. L., Dwyer, D. E., and Gilbert, L. National sero-survey of cytomegalovirus in Australia. Clin Vaccine Immunol. 2006; 13: 11811184.

16. Smith, D. M., Nakazawa, M., Freeman, M. L., et al. Asymptomatic CMV Replication During Early Human Immunodeficiency Virus (HIV) Infection Is Associated With Lower CD4/CD8 Ratio During HIV Treatment. Clin Infect Dis. 2016; 63(11):15171524.

17. Gianella, S., and Letendre, S. Cytomegalovirus and HIV: A Dangerous Pas de Deux. J Infect Dis. 2016; 214 (2): S67-74.

18. Manicklal, S., Emery, V.C., Lazzarotto, T. Boppana, S.B., and Gupta, R.K. The "Silent" global burden of congenital cytomegalovirus. Clin Microbiol Rev. 2013; 26 (1): 86-102.

19. Cannon, M. J., Schmid, D. S., and Hyde, T. B. Review of cytomegalovirus seroprevalence and demographic characteristics associated with infection. Rev Med Virol. 2010; 20: 202-213. $10.1002 / \mathrm{rmv}$

20. Gumbo, H., Chasekwa, B., Church, J. A., Ntozini $\mathrm{R}$, Mutasa K, Humphrey JH. et al. Congenital and postnatal CMV and EBV acquisition in HIV-infected Zimbabwean infants. PLoS One. 2014; 9 (12): e114870.doi:10.1371/journal.pone.0114870.

21. Chakraborty, R., Rees, G., Bourboulia, D., et al. Viral co-infections among African children infected with human immunodeficiency virus type 1 . Clin Infect Dis. 2003; 36: 922-924. 10.1086/368207.

22. Musa, A. M., Taura, D. W., Mukhtar, M. D., Koki, Y. A, and Adamu, S. Studies on Cytomegalovirus Infection among HIV Positive Patients Attending Infectious Diseases Hospital, Kano State, Nigeria.
Greener J Epidemiol Publ HIth. 2014; 2 (1): 3236.

23. Basawaraju, A., Pratibha, M. M., and Vijayadurga S. The Reactivation of Cytomegalovirus Infection in HIV Infected Patients. J Clin Diagnostic Res. 2011; 5: $749-751$

24. Neusa, M., Antonio, F., and Incilia, C. Research of Antigen and Antibodies from Retrovirus, CMV, and HBV among Prisoners of Penitentiary Complex of the Region of Comparinces. S.P. Brazil. Rev Int Med Trop Sao Paulo. 1998; 40 (4) http://dx.doi.org/10.1590/S0036-4665199800040 0001.

25. Turbadkar, D., Mathur, M., and Rele, $M$. Seroprevalence of TORCH Infection in Bad Obstetric History. Indian J Med Microbiol. 2003; 21 (2): $108-110$

26. Kfutwah, A. K. W., Ngoupo P. A. T, Sofeu, C. L., et al. Cytomegalovirus infection in HIV-infected versus non-infected infants and HIV disease progression in Cytomegalovirus infected versus non infected infants early treated with CART in the ANRS 12140-Pediacam study in Cameroon. BMC Infect Dis. 2017; 17: 224

27. Oladipo, E. K., Akinpelu, O. O., Oladipo, A. A., and Edowhorhu, G. Seroprevalence of Cytomegalovirus (CMV) among Blood Donors at Bowen University Teaching Hospital Ogbomoso. Am J Med Biol Res. 2014; 2 (3): 72-75

28. Tsertsvadze, T., Gochitashvili, N., Sharvadze, L. and Dvali, N. Cytomegalovirus Infection in HIV Patients. International Conference on AIDS, Infections Disease; AIDS and Clinical Immunology Research Center, Tbilisi, Georgia. 2002: 1 - 2

29. Akinbami, A. A., Akanmu, A. S., Adeyemo, T. A., Wright, K. O., Dada, M. O., and Dosunmu, A. O. Cytomegalovirus Antibodies among Immunocompromised (HIV) Patients at Lagos University Teaching Hospital (LUTH) Idi Araba, Lagos. J Med. 2010; 11(2): 151-154. doi: 10.3329/jom.v11i2.5462

30. Marawan, A. A., Jerzy, M. B., and Haydee, A. D. Toxoplasma gondii Seropositivity and Co-Infection with TORCH Pathogens in High-Risk Patients from Qatar. Am J Trop Med Hyg. 2010; 82 (4): 626633. doi:10.4269/ajtmh.2010.09-0530.

31. Ojide, C. K., Kalu, E. I., Nwadike, V. U., OgbainiEmovon, E., and Omoti, C. Seroprevalence of Cytomegalovirus among HIV-Infected Adult Patients on HAART. Int J Trop Dis Health. 2013; 3 (3): 233-241

32. Umeh, E. U., Onoja, T. O., Aguoru, C. U. and Umeh, J. C. Seroprevalence of Cytomegalovirus Antibodies in Pregnant Women, Benue State, Nigeria. Infect Dis Ther. 2015; 3: 242

33. Maingi, Z., and Nyamache, A. K. Seroprevalence of Cytomegalo Virus (CMV) among pregnant women in Thika, Kenya. BMC Res Notes. 2014, 7: 794.

34. Sufiawata, I., Widyaputra, S., and Djajakusamah, T. S. A study of cytomegalovirus serology among HIV infected patients in the highly active antiretroviral therapy era. Bandung Med J. 2013; 5 (2): 112-117.

35. Fowotade, A., Okonko, I. O., Agbede, O. O., and Suleiman, S. T. High seropositivity of IgG and IgM antibodies against cytomegalovirus (CMV) among HIV-1 seropositive patients in Ilorin, Nigeria. Afr Health Sci. 2015; 15 (1): 1-9.

36. Klatt, E. C., and Shibata, D. Cytomegalovirus infection in the acquired immunodeficiency syndrome: clinical and autopsy findings. Arch Pathol Lab Med. 1988; 112: 540-544

37. Udeze, A., Odebisi-Omokanye, M., and Ajileye, T. Cytomegalovirus infection among Human Immunodeficiency Virus (HIV) infected individuals 
on highly active anti-retroviral therapy in NorthCentral Nigeria. Afr HIth Sci. 2018; 18 (4): 1057 . 1065. https://dx.doi.org/10.4314/ahs.v18i4.27

38. Dowd, J. B., Aiello, A. E., and Alley, D. E. Socioeconomic disparities in the seroprevalence of cytomegalovirus infection in the US population: NHANES III. Epidemiol Infect 2009; 137: 58 - 65

39. Bernard, J. T. Human Cytomegalovirus Species. Classification of Viral Family (Herpesviridae). 2007; 2: 127-128

40. Basha, J. I., Iwasenko, J. M., Robertson, P., Craig, M. E., and Rawlinson, W. D. Congenital cytomegalovirus infection is associated with high maternal socio-economic status and corresponding low maternal cytomegalovirus seropositivity. J Paediatr Child Hlth. 2014; 50 (5): 368-72. doi:10.1111/jpc.12502.

41. Mehrkhani, F., Jam, S., Sabzvari, D., Fattahi, F., Kourorian, Z., and Seyed Alinaghi, $S$. Cytomegalovirus Co-Infection in Patients with Human Immunodeficiency Virus in Iran. Acta Medica Iranica. 2011; 49 (8): 551-555. 